\title{
Hibah Harta pada Anak Angkat (Telaah Filosofis terhadap Bagian Maksimal Sepertiga)
}

\author{
Nor Mohammad Abdoeh \\ Fakultas Syari' ah IAIN Salatiga \\ Email: abduhiainsalatiga@gmail.com
}

\begin{abstract}
Abstrak
Salah satu cara yang digunakan dalam hukum Islam untuk memperoleh harta adalah hibah. Proses penghibahan dalam hukum Islam tidak bisa dilepaskan dari batasan harta yang dihibahkan. Fenomena di masyarakat terkadang terjadi dualisme hukum yang kontradiksi antara hukum dalam teori dan hukum dalam praktek. Fenomena di masyarakat banyak orang yang menghibahkan hartanya kepada anak angkatnya dengan semua harta yang dimilikinya di depan Notaris. Hal ini menjadi sebuah persoalan tentang posisi anak angkat yang diartikan sebagai orang lain dan diartikan bukan sebagai ahli waris dan dapat dianggap sebagai orang asing yang dapat menerima hibah semua harta. Tujuan penulisan ini adalah untuk mengetahui akan hakekat adanya pembatasan sepertiga dalam hibah. Penelitian ini adalah penelitian pustaka dengan pendekatan kualitatif. Sumber data sekunder, dengan analisis deskriptif. Kesimpulan dari tulisan ini adalah bahwa konsep hibah dalam hadis maupun dalam kompilasi hukum Islam tidak dapat dilepaskan dari batasan harta yang boleh dihibahkan. Adanya batasan tersebut, tidak lain untuk memprioritaskan ahli waris atau keluarga di atas orang lain (anak angkat) dalam penerimaan harta. Karena meninggalkan ahli warisnya dalam keadaan berkecukupan lebih baik daripada meninggalkan ahli warisnya dalam keadaan miskin.
\end{abstract}

Keywords: Hibah, Anak Angkat, Sepertiga, Filosofis. 


\title{
Inheritance for Adopted Child (A Philosophical Study of a Maximum of One-Third)
}

\author{
Nor Mohammad Abdoeh \\ Faculty of Sharia State Institute for Islamic Studies (IAIN) Salatiga
}

\begin{abstract}
According to Islamic law, one of the ways to obtain inheritance is grant. According to Islamic law, grant is inseparable from the limitation of the inheritance being granted. However, legal dualism often occurs where there is contradiction between law in theory and law in practice. In fact, many people give/grant all their inheritance to their adopted children in front of a notary. This, however, becomes a problem since adopted children are seen as non family members who are not heir, thus they are considered as non family members who are allowed to receive grant of all inheritance. The objective of this paper is to find out about the purpose of one-third limitation in grant. This was a library research using a qualitative approach, a secondary data source, and a descriptive analysis. This paper concludes that the concept of grants in the hadith as well as in the compilation of Islamic law is inseparable from the limitation of inheritance that is allowed to be granted. Such limitation aims to prioritize heirs compared to non family members (adopted children) in receiving inheritance. This is because leaving the heirs in wealth is better than leaving the heirs in poverty.
\end{abstract}

\section{Keywords: Grant, Adopted Child, One-Third, Philosophical}

\section{PENDAHULUAN}

Sejarah perkembangan kehidupan manusia tak seorangpun yang dapat hidup menyendiri, terpisah dari kelompok manusia lainnya. Manusia sebagai individu (perseorangan) mempunyai kehidupan jiwa yang menyendiri, namun manusia sebagai makhluk sosial tidak dapat dipisahkan dari masyarakat. Manusia lahir, hidup, berkembang dan meninggal dunia di dalam masyarakat juga. ${ }^{1}$

1 C. S. T Kansil, Pengantar Ilmu Hukum Dan Tata Hukum Indonesia (Jakarta: Balai Pustaka, 1989), hlm. 29. 
Pedoman dalam agama Islam mengajarkan tata susunan masyarakat dengan akhlak yang baik dan bermartabat. Masyarakat tersusun dari para individu, dan individu ini harus memiliki kepercayaan kuat yang berpokok pada rukun iman keenam yang bernafaskan rukun hidup menurut Islam. $^{2}$

Proses dalam bermuamalah ada beberapa aqad yang perlu kita kenal, seperti persetujuan timbal balik, yaitu persetujuan yang menimbulkan kewajiban pokok kepada kedua belah pihak, seperti jual beli dan sewa menyewa. Adapun persetujuan sepihak adalah persetujuan dimana hanya terdapat kewajiban pada salah satu pihak saja misalnya wasiat ${ }^{3}$, warisan ${ }^{4} \&$ hibah. $^{5}$

Pengertian hibah itu sendiri secara etimologi bermakna pemberian, sedekah, pemindahan hak. ${ }^{6}$ Disisi yang lain hibah itu sendiri termasuk sebagai kategori hadiah dan şodaqoh yang merupakan salah satu dari berbagai macam hubungan hukum yang diatur dengan seperangkat aturan hukum. Adapun kepentingan untuk mengatur masalah hibah bertujuan agar tidak terjadi kesewenang-wenangan dalam pelaksanaan hibah tersebut apabila terjadi perselisihan dan juga pelaksanaan hibah sesuai dengan tata aturan yang ada.

Agama Islam telah mengatur tata cara manusia bermuamalah. Sedikitnya ada empat macam produk pemikiran hukum Islam yang dapat dijadikan pedoman atau acuan dalam menyelesaikan problematik kehidupan kemasyarakatan, khususnya dalam hal hibah, adapun produk dari hukum Islam itu sendiri yaitu: Kitab-kitab fiqih, fatwa-fatwa ulama, keputusankeputusan pengadilan, dan peraturan perundangan di negeri-negeri mus$\lim .^{7}$

2 Sjafa'at, Pengantar Studi Islam, Cet. I (Jakarta: Bulan Bintang, 1964), hlm. 102.

3 Umar Haris Sanjaya, "Kedudukan Surat Wasiat Terhadap Harta Warisan Yang Belum Dibagikan Kepada Ahli Waris," Jurnal Yuridis 5, no. 1 (2 Agustus 2018): 67-97, https://doi.org/10.35586/. v5i1.317.

4 Nursyamsudin Nursyamsudin, "Pembagian Harta Waris Sebelum Muwaris Meninggal Dunia Menurut Perspektif Hukum Waris Islam," Mahkamah: Jurnal Kajian Hukum Islam 3, no. 1 (8 Juni 2018): 69-85, https:// doi.org/10.24235/mahkamah.v3i1.2747.

5 R Setiawan, Pokok-Pokok Hukum Perikatan, Cet. 5 (Bandung: Bina Cipta, 1994), hlm. 50.

6 Sutan Rajasa, Kamus Ilmiah Populer (Surabaya: Karya Utama, 2002), hlm. 211.

7 Atho Mudzhar dan Mathori Alwustho, Membaca Gelombang Ijtihad: Antara Tradisi Dan Liberasi (Yogyakarta: Titian Ilahi Press, 1998), hlm. 91. 
Penguasaan dalam harta benda dapat terjadi dengan suatu bentuk aqad atau perjanjian pemindahan milik dari seseorang kepada orang lain. Dari banyak cara untuk memperoleh harta tersebut salah satunya adalah hibah. ${ }^{8}$ Di dalam hukum Islam, hibah berarti aqad yang pokoknya adalah pemberian harta milik seseorang kepada orang lain di waktu ia masih hidup tanpa adanya imbalan apapun. Secara umum hibah mempunyai pengertian meliputi hal-hal: $\mathrm{Ibra}^{\prime 9}$, Şodaqoh ${ }^{10}$ dan Hadiah. ${ }^{11}$

Dalam hal ini dapat dibedakan dalam dua hal, jika hibah itu diberikan kepada orang lain (selain ahli waris) atau suatu badan hukum, mayoritas pakar hukum Islam sepakat tidak ada batasnya, tetapi jika hibah itu diberikan kepada anak-anak pemberi hibah, menurut Imam Malik dan ahlu al-Zahir tidak memperbolehkannya, sedangkan Fuqaha Amsar menyatakan makruh. Sehubungan dengan tindakan Rasulullah SAW, terhadap kasus $\mathrm{Nu}$ 'man Ibnu Basyar menunjukkan bahwa hibah orang tua kepada anaknya haruslah disamakan bahkan banyak hadis lain yang redaksinya berbeda menjelaskan tidak bolehnya membedakan pemberian orang tua kepada anaknya secara berbeda, yang satu lebih banyak dari yang lainnya. ${ }^{12}$

Adapun hibah orang tua kepada anaknya dapat diperhitungkan sebagai waris. Apabila hibah akan dilaksanakan menyimpang dari ketentuan tersebut, diharapkan agar tidak terjadi perpecahan di antara keluarga. Sejatinya bahwa prinsip yang dianut oleh hukum Islam adalah sesuai dengan kultur bangsa Indonesia dan sesuai pula dengan apa yang dikemukakan oleh Muhammad Ibnul Hassan, bahwa orang yang menghilangkan semua hartanya itu adalah orang yang tidak layak bertindak hukum. Oleh karena itu orang yang menghibahkan semua hartanya dianggap tidak cakap bertindak hukum, maka hibah yang dilaksanakan dipandang batal, sebab ia tidak memenuhi syarat untuk melakukan penghibahan. Apabila perbua-

\footnotetext{
8 Ahmad Azhar Basyir, Asas-Asas Mu'amalah dalam Hukum Perdata Islam (Yogyakarta: Perpustakaan FH UII, 1993), hlm. 40.

9 Ibra ialah menghibahkan hutang kepada yang berhutang al-Sayyid Sabiq, Fiqih Sunnah (Jakarta, Indonesia: Pena Pundi Aksara, 2008), hlm. 168.

10 Şodaqoh yakni menghibahkan sesuatu dengan harapan mendapat pahala di akhirat Sabiq, hlm. 168.

11 Hadiah adalah pemberian yang menurut orang yang diberi itu untuk memberi imbalan Sabiq, hlm. 168.

12 Abdul Manan, Aneka Masalah Hukum Perdata Islam Di Indonesia (Jakarta: Kencana, 2006), hlm. 137.
} 
tan orang tersebut dikaitkan dengan kemaslahatan pihak keluarga dan ahli warisnya, sungguh tidak dibenarkan sebab di dalam syari' at Islam diperintahkan agar setiap pribadi untuk menjaga dirinya dan keluarganya dari api neraka. Dalam konteks ini ada kewajiban pada diri masing-masing untuk mensejahterakan keluarga. Seandainya perbuatan yang dilakukan itu menyebabkan keluarganya jatuh dalam keadaan miskin, maka sama halnya menjerumuskan sanak keluarganya ke gerbang kefakiran. ${ }^{13}$

Dalam praktek pelaksanaan hibah di pengadilan agama, sering dijumpai kasus pelaksanaan hibah yang dilakukan oleh seseorang kepada anak angkatnya dengan penghibahan semua harta yang dimilikinya. Ketentuan ini dilaksankan berdasarkan hukum positif sebagaimana tersebut dalam pasal 1682 KUH Perdata yaitu dilaksankan oleh dan dihadapan Notaris dan telah mendapat harta hibah sebagaimana ketentuan yang berlaku. ${ }^{14}$

Melihat kejadian ini tidak bisa dinafikan bahwa kehidupan masyarakat Indonesia hubungan anak angkat dan orang tua angkat tak ubahnya seperti hubungan anak kandung yang memiliki hubungan batin yang amat kuat, orang tua angkat merawat dan menyayangi anak angkatnya tanpa pamrih, sebaliknya anak angkat rela merawat dan mengurus orang tua angkat di masa tuanya tak ubahnya sebagai bagian dari sebuah keluarga. Bahkan hubungan batin antara anak angkat dengan orang tua angkat demikian kuatnya, tidak bisa dipungkiri hubungan ini seperti orangtua dan anak kandung sendiri, maka ketika orang tua angkat meninggal dunia dan anak angkat tidak mendapatkan warisan sedikitpun (karena bukan termasuk ahli waris), ataupun sebaliknya ketika anak angkat meninggal dan orangtua angkatnya tidak dapat mewarisi apa yang ditinggalkan oleh si anak angkat, tentu hal ini akan menimbulkan dampak yang luar biasa bagi kejiwaan. masalah ini merupakan problem tersendiri yang harus dicarikan solusinya agar prinsip

13 Manan, hlm. 138.

14 Hibah yang dimaksud adalah hibah yang dikuatkan dengan akta Notaris. Dalam konteks keIndonesia-an, akta adalah surat sebagai alat bukti yang diberi tanda tangan yang memuat peristiwa yang menjadi dasar suatu hak atau perikatan, yang dibuat sejak semula dengan sengaja untuk pembuktian Sudikno Mertokusumo, Hukum Acara Perdata Indonesia (Yogyakarta: Universitas Atma Jaya Yogyakarta, 2010), hlm. 149. 
keadilan yang dijunjung tinggi oleh Islam itu bisa terwujud dalam setiap produk hukum (aturan) yang ada. ${ }^{15}$

Polemik di atas ini menjadi sebuah pembahasan tentang keberadaan anak angkat yang diartikan sebagai orang lain dan diartikan bukan sebagai ahli waris dan dapat dianggap sebagai orang asing yang seolah-olah dapat menerima hibah semua harta. Hal inilah yang bertentangan dengan konsep hukum Islam yang selayaknya anak angkat diartikan sebagai orang lain yang hanya berhak menerima 1/3 bagian saja. Menghadapi persoalan ini, para praktisi hukum dituntut untuk arif dan bijaksana dalam menghadapinya. Sehingga permasalahan yang diselesaikan dan diputuskan sesuai dengan rasa keadilan. ${ }^{16}$

Dari pemaparan di atas, penyusun merasa perlu untuk mengkaji konsep asal muasal munculnya peraturan tentang bagian $1 / 3$ dalam hibah, yang bertujuan untuk mengetahui bagaimana konsep penghibahan harta dilihat dari kacamata filosofis. Oleh karena itulah penyusun ingin menulis jurnal yang berkaitan dengan hal tersebut dengan judul "Penghibahan Harta kepada Anak Angkat (Telaah Filosofis terhadap Bagian Maksimal 1/3 dalam Hibah)

Dari uraian di atas, dapat diambil beberapa pokok masalah yang dibahas lebih lanjut. Adapun pokok masalah yang penyusun angkat yaitu, Mengapa dalam hukum Islam merumuskan bagian dalam hibah yang berhak diterima anak angkat maksimal hanya 1/3 bagian dari keseluruan harta, apa yang melatarbelakanginya?

\section{METODOLOGI PENELITIAN}

Jenis pada penelitian ini adalah penelitian pustaka dengan pendekatan kualitatif yaitu memahami tentang apa yang dialami oleh suatu subjek penelitian baik yang berupa persepsi, motivasi, perilaku, tindakan dan lain-lain secara menyeluruh dan dengan cara mendeskripsikan dalam bentuk narasi, kata-kata dan bahasa.

Sumber data pada penelitian ini adalah sumber sekunder. Dalam hal ini

15 Ahmad Badrut Tamam, “Hibah : Sebuah Tawaran Solusi bagi Problematika Hukum Waris Islam" (Diktat, 2010), hlm. 4.

16 Tamam, hlm. 146. 
sumber tersebut adalah buku-buku atau tulisan yang menjelaskan dan relevan yang berkaitan dengan hibah harta. Metode pengumpulan data dalam penelitian ini dengan menggunakan metode dokumentasi. Metode analisis data dalam penelitian ini adalah analisis dekriptif, yaitu mendeskripsikan temuan dalam penelitian ini ke dalam bentuk tulisan-tulisan dan narasi.

\section{KONSEP PENGHIBAHAN HARTA MENURUT HUKUM ISLAM}

Mengenai konsep benda yang dihibahkan, bahwasannya benda meliputi segala macam yang wujud atau tidak ada ditempat (al-ma'dūm). Prinsipnya, semua benda atau hak yang dapat diperjualbelikan, maka dapat dihibahkan. Dalam konteks sekarang ini, seseorang mempunyai kekayaanbisa dalam berbentuk saham sebagai surat bukti bahwa ia memiliki benda yang diterangkan dalam surat tersebut. ${ }^{17}$

Dalam kompilasi hukum Islam, bahwa ukuran harta benda yang dihibahkan tidak boleh lebih dari $1 / 3$ bagian, yaitu berdasarkan pada aturan hukum: "Orang yang telah berumur sekurang-kurangnya 21 tahun, berakal sehat dan tanpa adanya paksaan dapat menghibahkan sebanyak-banyaknya 1/3 harta bendanya kepada orang lain atau lembaga dan dihadapan dua orang saksi"18.

Hal ini serupa dengan inti hadits Sa'ad ibn Abi Waqash yang berbunyi:

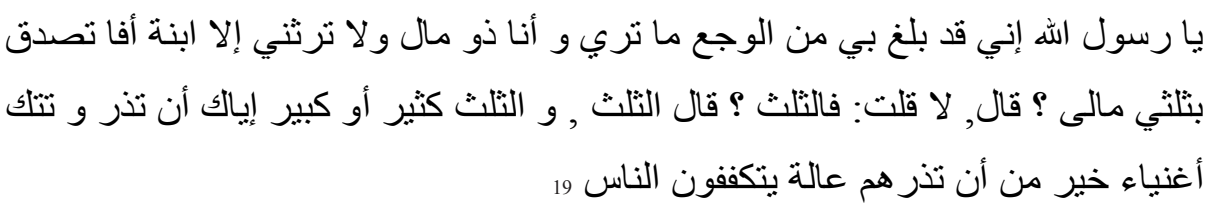

Berdasarkan hadist diatas, bahwasannya penghibahan harta setidaknya harus memperhatikan ahli warisnya. Dalil diatas adalah ijma, karena umat Islam sejak dari Rasulullah sampai saat ini banyak melakukan wasiat/hibah dan ternyata hal itu tidak pernah diingkari oleh seorang pun. Hal ini

17 Ahmad Rofiq, Hukum Islam Di Indonesia (RajaGrafindo Persada, 1995), hlm. 472.

18 Pasal 210, KHI.

19 Abũ '1-Husain Muslim ibn al Hajjãj al-Qushairī, A. 700/2:1 : Lathief Razak Rais, dan Inter Documentation Company, Shahih Muslim (Djakarta: Widjaya, 1957), hlm. 80. 
menunjukkan ada kesepakatan ijma umat Islam. ${ }^{20}$

Adapun ketika meninggalnya seseorang dengan meninggalkan cucu yang orangtuanya telah meninggal terlebih dahulu. Kompilasi Hukum Islam (KHI) memberikan solusi dengan diberikannya hak seorang ahli waris yang telah meninggal dunia kepada keturunannya yang masih hidup. Aturan ini tercantum dalam KHI yang bunyi lengkapnya adalah sebagai berikut:

1. Ahli waris yang meninggal dunia lebih dahulu dari pada si pewaris, maka kedudukannya dapat digantikan oleh anaknya, kecuali mereka yang tersebut dalam pasal 173. ${ }^{21}$

2. Bagian ahli waris pengganti tidak boleh melebihi dari bagian ahli waris yang sederajat dengan yang diganti. ${ }^{22}$

Dilihat dari tujuannya, pembaharuan hukum kewarisan tersebut dimaksudkan untuk menyelesaikan masalah dan menghindari sengketa.Dalam kaitannya dengan hal ini, Soepomodalam bukunya bahkan mengatakan bahwa munculnya institusi pergantian tempat didasarkan pada aliran pemikiran bahwa harta benda dalam keluarga sejak semula memang disediakan sebagai dasar material keluarga dan turunannya. Jika seorang anak meninggal sedang orangtuanya masih hidup, anak-anak dari orang yang meninggal dunia tersebut akan menggantikan kedudukan bapaknya sebagai ahli waris harta benda kakeknya. ${ }^{23}$

Secara tegas dalam buku pedoman pelaksanaan tugas dan administrasi peradilan agama tentang asas ahli waris langsung dan asas ahli waris pengganti.

1. Ahli waris langsung (eigen hoofed) adalah ahli waris yang disebut dalam pasal $174 \mathrm{KHI}$.

2. Ahli waris pengganti (plaatvervulling) adalah ahli waris yang diatur ber-

20 M. Ali Hasan, Berbagai Macam Transaksi Dalam Islam (figh Muamalat) (Jakarta: RajaGrafindo Persada, 2003), hlm. 93.

21 Pasal 185 ayat (1) KHI.

22 Pasal 185 ayat (2) KHI.

23 Shobirin, "Ahli Waris Pengganti dalam Kewarisan Islam Perspektif Mazhab Nasional," Ahli Waris Pengganti dalam Kewarisan Islam Perspektif MazhabNasional (blog), diakses 30 Januari 2013, http:// www.badilag.net/liputan-rakernas-2011/434-artikel diakses tanggal 30 Januari 2013. 
dasarkan Kompilasi Hukum Islam, Diantara ahli waris pengganti yang disebutkan dalam Buku II adalah :

a. Keturunan dari anak mewarisi bagian yang digantikannya.

b. Keturunan dari saudara laki-laki/perempuan (sekandung, seayah dan seibu) mewarisi bagian yang digantikannya.

c. Kakek dan nenek dari pihak ayah mewarisi bagian dari ayah, masing-masing berbagi sama.

d. Kakek dan nenek dari pihak ibu mewarisi bagian dari ibu, masingmasing berbagi sama.

e. Paman dan bibi dari pihak ayah beserta keturunannya mewarisi bagian dari ayah apabila tidak ada kakek dan nenek pihak ayah.

f. Paman dan bibi dari pihak ibu beserta keturunannya mewarisi bagian dari ibu apabila tidak ada kakek dan nenek pihak ibu. Selain yang tersebut di atas tidak termasuk ahli waris pengganti. ${ }^{24}$

Dari penjelasan tentang ahli waris pengganti, bahwa KHI dalam hal ini kedudukannya dapat digantikan oleh anaknya, kecuali mereka yang dipersalahkan telah membunuh atau mencoba membunuh atau menganiaya berat pada pewaris dan dipersalahkan secara memfitnah telah mengajukan pengaduan bahwa pewaris telah melakukan suatu kejahatan yang diancam dengan hukuman lima tahun penjara atau hukuman yang lebih berat. ${ }^{25} \mathrm{Da}-$ lam konsep kompilasi hukum Islam, bahwa penghibahan harta haruslah mempertimbangkan keturunan keluarganya yang walaupun sudah meninggal bisa digantikan oleh cucunya. Artinya ketika meninggalnya seseorang dengan meninggalkan cucu yang orangtuanya telah meninggal terlebih dahulu, maka harta yang boleh dihibahkan tetap tidak boleh lebih dari 1/3 bagian dan 2/3 bagiannya akan diberikan kepada ahli waris pengganti.

Ketika seseorang hidup dan tidak mempunyai ahli waris maupun keturunan, maka harta sepertiganya menjadi hak Baitul Mal (Perbendaharaan Negara). Akan tetapi, yang demikian itu bukanlah karena Baitul Mal dipandang sebagai ahli waris, tetapi karena harta itu tidak ada yang berhak men- 
erimanya. Hal ini yang ditetapkan Kompilasi Hukum Islam Pasal 191 dan Jumhur Fuqahayang mengatakan, bahwa Baitul Mal berhak mendapat harta atas sisanya, sebagai waris bagi orang yang tidak ada ahli waris. ${ }^{26}$

\section{NILAI-NILAI KEADILAN HUKUM DALAM HIBAH}

\section{Keadilan dalam Hukum Islam}

Islam mewajibkan umatnya untuk berbuat adil, hal ini berdasarkan atas firman Allah:

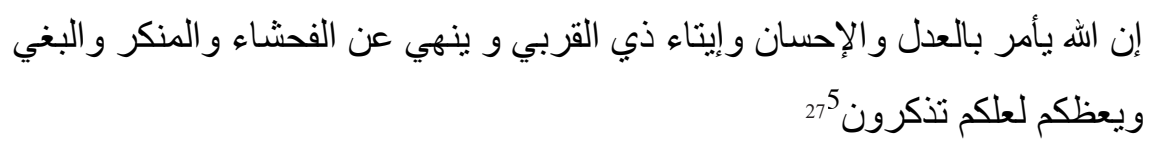

Dari ayat diatas bisa dipahami bahwa Allah SWT melarang umatnya untuk berbuat zalim kepada siapapun dan melarang umatnya berbuat zalim kepada orang lain dan menginjak hak orang lain. Tentunya, aturan dalam Islam mendorong manusia berperilaku lebih dari tutunan standar atau keadilan. Dari ayat tadi terdapat dua pelajaran yang dapat dipetik:'Pertama, Di samping keadilan, ihsān atau kebaikan juga dianjurkan. Sebab, ihsan akan menjaga ketulusan di tengah masyarakat. Kedua, Ajaran agama selaras dengan akal dan fitrah manusia. Kecenderungan pada keadilan dan ihsan serta jauh dari perbuatan munkar adalah tuntutan-tuntutan semua manusia yang sekaligus perintah Allah Swt.

Menurut Hasby Ash-Shiediqie, pada dasarnya suatu keadilan tertinggi adalah keadilan Tuhan yang mutlak, tetapi mekanisme persidangannya tidak terlalu berbeda dengan penerapan prinsip keadilan di dunia. Hanya keadilan Allah yang tidak dapat dibantah oleh makhluknya. ${ }^{28}$

Adapun keadilan dalam Islam dalam bukunya Abdul Ghofur An-

26 Teungku Muhammad Hasbi Ash-Shiddieqy, Figh Mawaris: Hukum Pembagian Warisan Menurut Syariat Islam (Semarang: Pustaka Rizki Putra, 2010), hlm. 257. 90.

27 Al-Qur'an Tajwid Warna, Terjemah Indonesia: Plus Transliterasi Latin (Shahih, 2015) An-Nahl (16):

28 Muhammad Hasbi Ash- Shiddieqy, Peradilan Dan Hukum Acara Islam (PT. Alma'arif, Jakarta, 1984), hlm. 11. 
shori bahwa keadilan merupakan perpaduan harmonis antara hukum dengan moralitas, Islam tidak bertujuan menghancurkan kebebasan individu, tetapi mengontrol kebebeasan itu demi keselarasan dan harmonisasi masyarakat yang terdiri dari individu-individu itu sendiri. Hukum Islam memiliki peran dalam mendamaikan pribadi dengan kepentingan kolektif, bukan sebaliknya. Individu diberi hak untuk mengembangkan hak pribadinya dengan syarat tidak mengganggu kepentingan orang banyak. ${ }^{29}$

Menurut Baiquni bahwa hakekat sebuah keadilan adalah at-tawaşatu baina al-amraini yaitu berdiri di tengah-tengah antara dua perkara. Hal inilah yang menjadikan keadilan dalam hukum Islam tidak dapat dilepaskan dari acuan wahyu illahi. Tujuan keadilan melalui jalur hukum harus berawal dari dua segi dan mengarah kepada keadilan dua segi pula. Hal ini dikarenakan wahyu di satu segi harus mampu menyatu dengan pedoman prinsip keadilan secara umum menurut pandangan manusia di lain segi. Karena itulah tugas awal yang kemudian dihadapi adalah formulasi Al-Qur'an dan hadist agar mampu tampil sesuai dengan prinsip keadilan secara umum. Hal ini merupakan sesuatu keniscayaan dikarenakan Islam memberikan peluang dalam tataran fikih untuk melakukan formulasi hukum yang sesuai dengan rasa keadilan masyarakat pada suatu waktu dan tempat tertentu. ${ }^{30}$

Dalam gagasannya Ginanjar, bahwa keadilan merupakan fitrah yang telah dimiliki manusia. Dengan karunia fitrah, bila manusia hendak berbuat tidak baik, pasti akan dilarang oleh suara hati nuraninya, sebab Tuhan tidak menghendaki manusia berbuat tidak baik. Kalau ma-

29 Abdul Ghofur Anshori, Filsafat Hukum Sejarah, Aliran Dan Pemaknaan (Yogyakarta: Gadjah Mada University Press, 2006), hlm. 63.

30 Maksud dari muara keadilan dua segi adalah tujuan akhir berupa keadilan yang harus dicapai oleh sebuah system hukum universal berorientasi pada keadilan terhadap manusia (makhluk) dan keadilan kepada Allah (khaliq). Keadilan bagi manusia mengarah pada berbagai definisi keadilan yang bukan tidak mungkin antara satu masyarakat manusia dengan yang lainnya berbeda dalam mengartikan keadilan hukum. Artinya fleksibilitas produk keadilan mutlak diperlukan dalam heterogenitas manusia dan lingkungannya, sedangkan muara keadilan kepada Allah adalah produk yang tetap menempatkan Allah sesuai dengan proporsinya sebagai Tuhan. Kegiatan manusia dalam upaya formulasi tujuan hukum berupa keadilan harus tetap berada dalam koridor ibadah kepada-Nya dkk. Baiquni, Ensiklopedi Al-Qur'an Dunia Islam Modern (Yogyakarta: PT Dana Bhakti Prima Yasa, 2002), hlm. 110; Abdul Ghofur Anshori, Filsafat Hukum Hibah Dan Wasiat Di Indonesia (Yogyakarta: Gadjah Mada University Press, 2011), hlm. 108. 
nusia tetap mengerjakan perbuatan yang tidak baik itu, maka suara hatinya akan memberikan nasehat. Bila kemudian telah selesai mengerjakan perbuatan tidak baik itu, maka manusia pasti akan menyesal. Suara-suara hati ini adalah merupakan cerminan dari sifat-sifat Allah (asmaul husna) yang dimiliki oleh orang di seluruh dunia. Tidak peduli apakah ia seorang yang kaya, miskin, rasa apa saja, agama apa saja, berbagai suku apapun namanya, akan merasakan suara hati yang sama, apabila dalam kondisi fitrah. Fitrah atau suara hati yang sama dari semua orang di dunia ini dikenal dengan anggukan universal. ${ }^{31}$

Konsep keadilan yang dianggap tidak akan pernah selesai merupakan hasil dari tertutupnya suara hati. Dengan tertutupnya hati maka akan berakibat manusia cenderung terjerumus ke dalam kejahatan, kecurangan, kekerasan, kerusakan, kehancuran dan perbuatan tidak adil lainnya. Agustian menjelaskan sedikitnya tujuh factor yang menyebabkan tertutupnya fitrah manusia. Tujuh hal tersebut adalah prasangka, prinsip-prinsip hidup, pengalaman, kepentingan dan prioritas, sudut pandang, pembanding dan terakhir adalah literature. Akhirnya dapat dinyatakan bahwa keadilan adalah sesuatu yang spiritual yang hanya dapat dipahami oleh hati yang bersih. ${ }^{32}$

\section{Nilai Keadilan dalam Hibah}

Dalam Islam banyak sekali dijumpai seruan-seruan untuk berbuat adil. Adil dalam pluralisme system hukum yang ada di Indonesia, utamanya dalam permaslahan hibah ternyata terwujud dalam perspektif yang berbeda. Untuk itulah perlunya adanya perbandingan dan penggalian mengenai keadilan dalam hibahmenurut tiga system hukum tersebut.

31 Maksud dari anggukan universal adalah bahwa sebenarnya keadilan merupakan perasaan murni manusia yang terdapat dalam setiap hati. Keadilan ini berlaku universal sebagaimana anggukan universal sehingga setiap orang pada hakekatnya memiliki persepsi keadilan yang sama. Karenanya permasalahan perdebatan mengenai makna keadilan ini dapat diakhiri dengan memandang keadilan sebagai kebenaran universal yang diakui oleh hati nurani. Lihat Ary Ginanjar Agustian, Rahasia Sukses Membangun Kecerdasan Emosi Dan Spiritual Esq: Emotional Spiritual Quotient Berdasarkan 6 Rukun Iman Dan 5 Rukun Islam (Jakarta: Arga Wijaya Persada, 2001), hlm. 9.

32 Agustian, hlm. 12. 


\section{a. Nilai Keadilan dalam Pemaknaan Hibah}

Pada dasarnya makna yang terkandung dalam Kompilasi Hukum Islam tidak jauh berbeda dengan makna yang ada dalam KUHPerdata. Dalam Kompilasi Hukum Islam disebutkan bahwa makna hibah ialah : Pemberian suatu benda secara sukarela dan tanpa imbalan dari seseorang kepada orang lain yang masih hidup untuk dimiliki". ${ }^{33}$ Adapun dalam KUHPerdata makna hibah (schenking) itu sendiri yaitu suatu perjanjian dengan mana si penghibah, di waktu hidupnya dengan cuma-cuma dan dengan tidak dapat ditarik kembali untuk menyerahkan suatu benda guna keperluan si penerima hibah yang menerima penyerahan. ${ }^{34}$ Berdasarkan uraian diatas dapat disimpulkan bahwa nilai substansi dalam pemaknaan hibah dari kedua hokum mempunya kesamaan yaitu : Pertama, Suatu akad pemberian milik harta kepada sesuatu pihak. Kedua, Pemberian dilakukan semasa penghibah masih hidup. Ketiga, Harta yang boleh dihibahkan ialah harta, bukannya hutang. Keempat, Akad hibah dibuat tanpa ada syarat imbalan. Kelima, Akad dibuat secara sukarela atau cuma-cuma dan tanpa paksaan. Keenam, Tidak dapat ditarik kembali.

Makna pemberian ini kemudian berkaitan dengan keadilan (kebolehan) penarikan atau pencabutan hibah. Dalam hukum perdata BW pada hakekatnya hibah tidak dapat ditarik kembali maupun dihapuskan, demikian juga dengan hukum Islam yang melarang (haram) penarikan kembali pemberian. Bahkan dalam Islam penarikan hibah ini dipersamakan dengan anjing yang muntah lalu memakan muntahnya kembali. Ketidakbolehan penarikan kembali dikarenakan makna hibah dalam hukum Islam dan hukum perdata BW adalah pemberian Cuma-Cuma (omniet) dan tidak mengharapkan suatu kontraprestasi apapun atau dengan kata lain yakni pemberian secara ikhlas. ${ }^{35}$

35 Anshori, Filsafat Hukum Hibah Dan Wasiat Di Indonesia, hlm. 113. 
Pada dasarnya dalam hukum Islam, kaitannya dalam penarikan kembali atas sesuatu pemberian adalah merupakan perbuatan yang diharamkan, meskipun hibah tersebut terjadi antara dua orang yang bersaudara atau suami istri. Adapun hibah yang boleh ditarik kembali hanyalah hibah yang dilakukan atau diberikan orang tua kepada anknya. ${ }^{36}$

Meskipun tertutup kemungkinan untuk menarik kembali hibah yang telah diberikan, kecuali pemberian atau hibah kepada anaknya, pemberian hadiah dapat menarik kembali hibahnya kepada orang yang menerima hibah seandainya orang yang member hibah itu tidak menerima imbalan atau balasan dari orang yang menerima hibah, padahal imbalan dan balasan yang baik dari orang yang menerima hadiah itu sangat diharapkan karena sekarang ia sudah udzur. Misalnya seorang yang telah lanjut usia memberikan hibah kepada orang tertentu dengan harapan orang yang menerima hibah itu mau merawatnya. Tetapi setelah hibah diberikan, orang yang yang menerima hibah tidak mau memperhatikan nasib orang yang memberikan hibah. Dalam kondisi ini tidak ada halangan bagi orang yang memberi hibah ini menarik kembali. ${ }^{37}$

Adapun penarikan hibah dimaksudkan agar orang tua dalam memberikan hibah kepada anak-anaknya, atau orang tertentu kiranya bisa memperhatikan nilai-nilai keadilan dan menjaga kemaslahatan bagi anak-anaknya dan orang yang bersangkutan tersebut. Kebolehan ini juga mendukung system hubungan orang tua dan anak dalam Islam, karena dalam Islam harta anak laki-laki dapat diambil orang tuanya (bapak)..$^{38}$

\section{b. Nilai Keadilan Pembatasan Porsi Sepertiga dalam Hibah}

Kompilasi Hukum Islam menganut prinsip bahwa hibah hanya boleh di dilakukan sepertiga dari harta yang dimilikinya, hal ini ber-

36 Manan, Aneka Masalah Hukum Perdata Islam Di Indonesia, hlm. 139.

37 Suhrawardi K. Lubis dan H. Chairuman Pasaribu, Hukum Perjanjian Dalam Islam, vol. 1994 (Jakarta: Sinar Grafika, 1994), hlm. 391.

38 Anshori, Filsafat Hukum Hibah Dan Wasiat Di Indonesia, hlm. 113. 
dasarkan pada pasal 210 Kompilasi Hukum Islam ${ }^{39}$, adapun hibah orang tua kepada anaknya bisa diperhitungkan sebagai waris. Apabila hibah akan dilaksanakan menyimpang dari ketentuan tersebut, diharapkan tidak terjadi perpecahan diantara keluarga. Prinsip dalam hukum Islam adalah sesuai dengan kultur banggsa Indonesia. Dalam konteks ini ada kewajiban pada diri masing-masing untuk menyejahterakan keluarga, seandainya apa yang dilakukan ini menjadikan keluarganya terjatuh dalam keadaan miskin, maka sama halnya ia menjerumuskan sanak familinya ke gerbang kekafiran. ${ }^{40}$

Pada hakekatnya adanya sebuah hukum ternyata mengatur dan membatasi kebebasan kepemilikan atas suatu hak. Hak milik (eigendom ${ }^{41}$ ) meskipun dalam konsep KUHPerdata merupakan hak mutlak namun kenyataan hukum menunjukkan bahwa terdapat pembatasan-pembatasan tertentu dalam mempergunakannya. Terkait pemberian hibah yang diperhitungkan sebagai warisan, dapat dikatakan bahwa pemberian hibah tersebut tidak boleh menafikan keberadaan ahli waris atau merugikan ahli waris. Artinya kebebasan dari subjek hak milik dalam memberikan harta sesukanya terbentur pada keberadaan ${ }^{42}$ legitime portie. ${ }^{43}$

Bahwa tujuan dari pembuat undang-undang dalam menetapkan adanya legitime portie ini adalah untuk menghindari dan melindungi anak si wafat dari kecenderungan si wafat menguntungkan orang lain. Jadi kalau ditelaah lebih lanjut bahwa hukum Islam dan hu-

39 Pasal 210 Kompilasi hukum Islam: Orang yang telah berumur sekurang-kurangnya 21 tahun, berakal sehat dan tanpa paksaan, dapat menghibahkan sebanyak-banyaknya-banyaknya sepertiga harta bendanya kepada orang lain atau lembaga di hadapan dua orang saksi untuk dimiliki.

40 Manan, Aneka Masalah Hukum Perdata Islam Di Indonesia, hlm. 138; hilat juga Rahmat Wahyudi, "Hibah Melebihi Sepertiga Harta (Studi Kasus di desa Bonagung Kecamatan Tanon Kabupaten Sragen" (IAIN Walisongo, 2011), hlm. 32.

41 Eigendom ialah hak untuk menikmati kegunaan sesuatu benda dengan sepenuhnya dan untuk berbuat sebebas-bebasnya terhadap benda itu, asal tidak bertentangan dengan undang-undang atau peraturan umum yang ditetapkan oleh suatu kekuasaan yang berwenang menetapkannya, dan tidak menimbulkan gangguan terhadap hak-hak orang lain, dengan tidak mengurangi kemungkinan pencabutan hak itu untuk kepentingan umum berdasarkan atas ketentuan undang-undang dengan pembayaran ganti kerugian. Pasal 570, KUH Perdata.

42 Anshori, Filsafat Hukum Hibah Dan Wasiat Di Indonesia, hlm. 113.

43 Adapun makna dari legitime portie adalah Bagian Mutlak atau legitime Portie, adalah sesuatu bagiam dari harta peninggalan yang harus diberikan kepada waris, dalam garis lurus menurut undangundang, terhadap mana si yang meninggal tak diperbolehkan menetapkan sesuatu, baik selaku pemberian antara yang masih hidup, maupun selaku wasiat. Pasal 913 KUHPerdata. 
kum perdata hal ini sama memberikan batasan hak si penghibah dalam membuat hibah wasiat. ${ }^{44}$

Dalam hukum Islam pembatasannya lebih tegas karena kepemilkan harta bermakna sebagai titipan dari Yang Maha Memiliki. Pembatasan tersebut yaitu bahwa hibah tidak boleh melebihi sepertiga harta warisan. Dalam Islam, orang yang menghibahkan keseluruhan hartanya dianggap sebagai orang bodoh sehingga perbuatannya dapat dibatalkan. Batasan sepertiga ini merupakan batasan baku yang ditentukan Rasulullah sendiri, yakni bahwa menurut beliau sepertiga sudah banyak. ${ }^{45}$

Ajaran Islampun memberikan arahan tentang betapa pentingnya keadilan dalam pembagian harta. Tidak dihalalkannya bagi seseorang dalam pemberian harta melebihkan sebagian anak-anaknya di atas anak-anaknya yang lain, karena yang demikian akan menanamkan permusuhan dan memutuskan hubungan silaturrahim yang diperintahkan Allah untuk menyambungnya. ${ }^{46}$

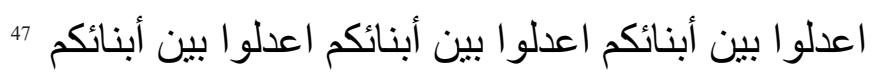

Konsep keadilan dalam pembagian harta, diumpamakan yang terjadi diantara mereka mengenai persamaan diantara anak-anak dan persamaan kebaktian dari anak-anak itu merupakan alasan yang menunjukkan bahwa perintah menunjukkan sunnah. Ini ditolak dengan tidak adanya persamaan dan larangan pelebihan seorang anak atas anak yang lain. Keduanya menunjukkan bahwa perintah itu untuk wajib. Dengan demikian maka alasan itu tidak pantas untuk memalingkan dari wajib ke dalam sunat. Kalaulah itu pantas, tentulah perintah itu dipalingkan kepada sunat. ${ }^{48}$

44 S. H. Oemarsalim, Dasar-Dasar Hukum Waris Di Indonesia (Bina Aksara, 1987), hlm. 86.

45 Anshori, Filsafat Hukum Hibah Dan Wasiat Di Indonesia, hlm. 113.

46 Sabiq, Fiqih Sunnah, hlm. 175.

47 Berbuat adillah terhadap anakmu, Berbuat adillah terhadap anakmu, Berbuat adillah terhadap anakmu. Muhammad ibn Ismā‘īl Bukhārī, Shahih Bukhary. (Al-Asriyah, Surabaya, 1979), hlm. 233.

48 Sabiq, Fiqih Sunnah, hlm. 181. 
Dalam hukum adat dapat dikatakan, bahwa tidak diperbolehkan seorang peninggal warisan dalam hibah menyampingkan seorang anak sama sekali dari pembagian harta (onterfd). Juga diperhatikan, bahwa meskipun ada hibah, tetap berlaku penentuan bahwa dari harta harus dibayar dulu hutang-hutang yang masih ada. Sehingga tidak ada sisa yang masih dapat dibagi-bagi menurut kehendak si pemberi hibah. Dalam hukum Islam sebanyak-banyaknya sepertiga bagian harta setelah dikurangi dengan hutang-hutangnya si pemberi hibah, utuk dapat diberikan kepada orang lain maupun anak angkat. Dengan kata lain perkataan 2/3 bagian harus disediakan untuk para ahli waris. Malahan apabila para ahli waris itu miskin, sangat dianjurkan supaya bagian harta yang diberikan kepada orang lain tadi, diperkecil sangat kurang dari sepertiga bagian. Peristiwa ini sering terjadi ketika seorang muslim menyerahkan sebagain hartanya supaya dipergunakan untuk kepentingan umum berupa pemberian sebidang tanah untuk pembangunan masjid, hal ini kiranya harus mndasarkan atas kondisi keadaan keluarga. ${ }^{49}$

\section{ANALISIS TERHADAP BATASAN MAKSIMAL SEPERTIGA DA- LAM ATURAN HIBAH}

\section{Dari Aspek Ontologis Sepertiga dalam Hibah}

Pada dasarnya dari segi ontologis, bahwa hakekat keberadaan hukum dengan segala bentuknya merupakan kehendak hati nurani manusia yang mengharapkan kehidupan yang aman, tenteram, damai, sejahtera, dan merasakan nikmatnya keadilan. ${ }^{50}$ Keberadaan manusia sebagai khalifah di muka bumi ini merupakan ciptaan Allah SWT yang menjadi subjek dari sebuah hukum. Tujuan diciptakan manusia di muka bumi ini tidak lain hanyalah untuk menyembah dan beribadah kepada Allah SWT. ${ }^{51}$

70 .

49 Wirjono Prodjodikoro, Hukum Warisan Di Indonesia (Bandung: Sumur Bandung, 1983), hlm.

50 Efran Helmi Juni, Filsafat Hukum, Cet. I (Bandung: Pustaka Setia, 1980), hlm. 5.

51 Hal ini berdasarkan ayat Al-Qur'an Adz-Dzariyat (51): 56. Dan Aku tidak menciptakan jin dan manusia melainkan supaya mereka mengabdi kepadaku. 
Tidak bisa dipungkiri bahwa hakekatnya manusia sebagai subjek hukum memiliki karakter yang berbeda-beda antara satu dengan yang lainnya. Kikir, suka berbohong, berbuat zalim, mengingkari petunjuk dan nikmat, suka membantah, suka melampaui batas, suka tergesa-gesa. Inilah potret atau karakter manusia. Tetapi di lain sisi manusia merupakan sebaik-baik makhluk yang telah diciptakan dengan segala kelebihannya. Al-Qur'an juga menunjukkan bahwa manusia adalah makluk yang berfikir. Dan setiap apa yang dikerjakan manusia akan dipertanggungjawabkan di akherat nantinya. ${ }^{52}$

Dari gambaran di atas dapat dipahami bahwasannya manusia harus senantiasa mawas atau berhati-hati serta memperhatikan dasar-dasar yang ada dalam sebuah aturan. Dalam memahami polemik yang ada dalam hibah, kiranya manusia harus memikirkan matang-matang hal yang paling mendasar kaitannya eksistensi manusia itu sendiri yang mengharapkan kemaslahatan dari adanya setiap hukum. Karena dalam menyelesaikan hibah seharusnya semata-mata bisa diterima oleh semua pihak.

Dengan demikian keberadaan dasar-dasar hukum Kompilasi Hukum Islam kaitannya batas maksimal sepertiga nyantanya sangat berpengaruh sekali dalam masyarakat dan dapat mengakomodir realitas empiris sebagaimana dikandung dalam nilai-nilai hukum yang telah ada di tengah masyarakat Indonesia yang mayoritas muslim. Dasar hukum tentang hibah kaitannya pembagian tidak melebihi sepertiga harta keseluruhan yaitu mempertimbangkan nilai-nilai sebuah kemaslahatan, keadilan dan ketenteraman tanpa saling iri secara sosial dalam pembagian tersebut. ${ }^{53}$

Hakekat adanya batas maksimal sepertiga bagian untuk anak angkat tidak lain untuk memberikan kemaslahatan bagi anak angkat itu sendiri yang walaupun bukan sebagai ahli warisnya, tetapi dia masih bisa mendapatkan harta dan tidak serta merta harta yang dia dapatkan tidak boleh melebihi ahli waris dari si Penghibah.

52 Anshori, Filsafat Hukum Hibah Dan Wasiat Di Indonesia, hlm. 125.

53 Anshori, hlm. 125. 


\section{Dari Aspek Epistemologi Sepertiga dalam Hibah}

Pada dasarnya epistemologi itu ialah sebuah teori asal mula timbulnya sebuah hukum dan bagaimana hukum itu ada. Secara epistemologis hukum merupakan jelmaan firman Tuhan. Hakekat hukum bukan berada pada teoriya, melainkan terletak pada realitasnya. Adapun epistemologi hukum mencoba menjawab pertanyaan-pertanyaan tentang prosedur perolehan pengetahuan tentang hukum, kebenaran dan tekniknya. ${ }^{54}$ Berkaitan dengan hukum hibah, teori epistemologi mencoba menjawab sebuah pertanyaan tentang prosedur perolehan sebuah pengetahuan tentang dasar hukum yaitu kebenarannya, dan tekniknya. ${ }^{55}$

Seperti yang dijelaskan sebelumnya bahwa proses muncul dan berlakunya tata aturan dalam hibah di Indonesia tidak lepas dari unsur politik yang mempengaruhinya, terlebih Indonesia merupakan negara yang mayoritasnya Islam. Kecenderungan setiap umat Islam untuk memberikan nilai-nilai dasar keIslaman dari setiap peraturan yang ada merupakan sesuatu hal yang tidak bisa dinafikan. Dengan hal ini, maka terbitlah Kompilasi Hukum Islam sebagai aturan yang berisi pasal-pasal yang mengatur tentang hibah khususnya terkait batasan maksimal sepertiga dalam hibah. Batasan maksimal sepertiga ini sejalan dengan apa yang dikemukakan Rasulullah di dalam hadisnya sebagai berikut:

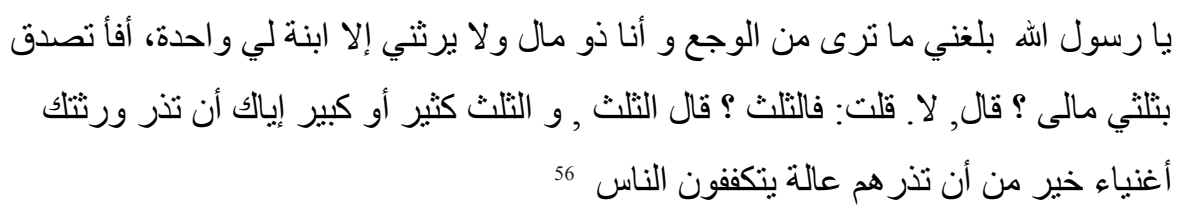

Nabi Muhammad SAW selain sebagai Rasul, nabi juga menjadi sumber hukum dalam agama Islam untuk dijadikan pedoman dan sendi-sendi hukum dalam menjalankan syariat agama. Keberadaan

54 Helmi Juni, Filsafat Hukum, hlm. 5.

55 Asmoro Achmadi, Filsafat Umum (RajaGrafindo Persada, 2001), hlm. 5.

56 Abũ 'l-Husain Muslim ibn al Hajjãj al-Qushairī, Razak, dan Inter Documentation Company, Shahih Muslim, hlm. 80. 
aturan-aturan dalam agama yang diharapkan untuk dilaksanakan dan tidak untuk dilanggar oleh umatnya merupakan bentuk keseriusan agama Islam dalam mengatur kehidupan manusia agar tercipta kedamaian, ketentraman dan kemaslahatan.

Hal ini tidak lepas dari kaidah fikhiyah yaitu:

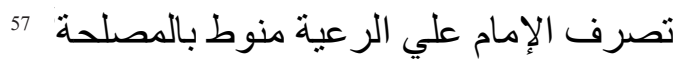

Bahwa berdasarkan kaidah ini, kiranya setiap seseorang yang memberikan suatu kebijakan haruslah mendatangkan suatu kemaslahatan dan terjauh dari kemudharatan. Dalam hal ini Rasulullah sebagai syari' dalam memberikan kebijakan sepertiga dalam hibah sangatlah mengedepankan kepentingan keluarga di atas kepentingan orang lain. Karena dalam Al-Qur'an sendiri mewajibkan bagi umatnya untuk menjaga dirinya sendiri dan keluarganya dari api neraka.

Pada dasarnya substansi dari epistemologi fikih adalah untuk mengetahui tentang suatu cara agar dapat mengetahui pesan-pesan syara' yang terdapat dalam Al Quran dan Hadis sehingga dapat diaplikasikan dalam berbagai perbuatan. Pengkajian tersebut dalam Islam terwujud dalam uşūlu al-figh yang didalamnya memerlukan berbagai macam keilmuan agar tujuan dari syara' (memelihara agama, diri, akal, keturunan dan harta) tetap terjaga. ${ }^{58}$ Dengan demikian keberadaan fikih sebagai syari'ah atau aturan hukum Islam harus menjadi sumber referensi kaitannya persoalan hibah, supaya substansi hikmahnya tercapai.

Hal ini juga sejalan dengan adanya batasan sepertiga dalam hibah yang tertuang dalam KHI di dalam tata hukum Indonesia yang bersubtansi hukum Islam itu jelas merupakan produk keputusan politik. Instrument hukum politik yang digunakan adalah Inpres

57 H. A. Djazuli, Kaidah-Kaidah Fikih: Kaidah-Kaidah Hukum Islam Dalam Menyelesaikan MasalahMasalah Yang Praktis (Prenada Media, 2006), hlm. 147.

58 Noor Ahmad, Epistemologi Syara' Mencari Format Baru Figh Indonesia (Yogyakarta: Pustaka Pelajar, 2009), hlm. 45. 
No.1 tahun 1991. Selain formulasi hukum Islam dalam tata hukum Indonesia, Kompilasi Hukum Islam bisa disebut sebagai representasi dari sebagian substansi hukum material Islam yang dilegislasikan oleh penguasa politik pada zaman orde baru.

Dengan demikian Kompilasi Hukum Islam mempunyai kedudukan yang penting dalam tata hukum Indonesia. Karena merupakan sebuah produk hukum dari proses politik orde baru. Karena itu selain bersifat nisbi, Kompilasi Hukum Islam dengan segala bentuknya, kecuali ruh hukum Islamnya, merupakan cerminan kehendak sosial para pembuatnya

Berkaitan dengan suatu cara dalam memperoleh pengetahuan hukum hibah ini tentu saja menggunakan metode. Tidak bisa dipungkiri bahwa Syariat Islam merupakan sumber hukum Islam yang menjadi tatanan kehidupan bagi umat. Karena kedudukannya bersumber dari Allah SWT, maka dalam prakteknya manusia sangatlah butuh penjelasan dan penafsiran akan kaidah hukum yang ada di dalamnya. Dalam rangka memahami secara utuh tentang hibah maka harus dengan menggunkan sebuah metode ijtihad, yaitu sebagai berikut: ijma' ulamā', qiyās, istihsān, maşlahah mursalah, sadu $a d z$-dzarā'i dan lain sebagainya.

\section{Dari Aspek Aksiologi Sepertiga dalam Hibah}

Aksiologi merupakan suatu pendekatan yang mencoba untuk memahami hukum dari segi manfaatnya, baik pragmatisme hukum maupun kemaslahatan dalam arti substansinya. Hukum dapat dijadikan alat atau media untuk mencapai manfaat duniawi dan ukhrawi, juga manfaat yang ditetapkan oleh kehidupan manusia yang relatif. ${ }^{59}$ Dalam perspektif falsafah hukum Islam, kemaslahatan yang dituangkan oleh hukum berupa tujuan hukum yang berusaha memelihara agama, akal, jiwa, keturunan, dan harta kekayaan atau dapat disebut sebagai maqasidu syari'ah. ${ }^{60}$

59 Helmi Juni, Filsafat Hukum, hlm. 6.

60 Abu Ishaq Ibrahim bin Musa bin Muhammad Al-Lakhmi Asy-Syathibi, Al-Muwafaqat Fi Usul Al-Shari'ah (Misr Matba'at al maktabah al-tujariyah, 1920), hlm. 20. 
Dalam aspek aksiologi hibah kaitannya bagian maksimal sepertiga dapat dipahami melalui hakekat hubungan antara si pemberi dengan si penerima. Karena aspek aksiologi berupaya mengetahui hakikat esensi nilai yang terdapat di dalam hibah itu sendiri. Fokus dari nilai disini adalah mengenai baik dan buruk dari sudut pandang moral dan etika dan manfaat. ${ }^{61}$

Paradigma persaudaraan dan kasih sayang inilah yang seharusnya mendasari lembaga hibah dalam hukum Islam di Indonesia. Mengingat Islam memiliki landasan ontologis dari yang maha besar berupa syari'ah, maka hukum Islam harus didekati dengan caracara yang bernafaskan syari'ah. Adalah hal yang keliru mendekati hukum Islam, dalam masalah hibah dengan pendekatan konflik yang berpaham egoistic individualistic. Dalam hukum hibah tidak menyatakan bagianmu dan bagianku secara dikotomis namun mencari bagaimana tercapai kerelaan hati diantara subjek yang terlibat dalam permasalahan hibah. ${ }^{62}$

Berkaitan dengan hibah, maka aksiologi fungsinya adalah untuk membimbing manusia dalam menangkap maksud Tuhan secara benar. Artinya dengan mempelajari dasar-dasar hukum yang ada dalam hibah seseorang dapat menangkap makna yang terkandung dalam teks-teks al-Qur'an dan assunnah maupun Kompilasi hukum Islam, sehingga sejalan dengan yang dikehendaki oleh Tuhan.

Dengan adanya pemahaman yang benar tentang maksud Tuhan dalam Al-Qur'an, Hadis maupun di dalam Kompilasi Hukum Islam tersebut, diharapkan seseorang akan mencapai suatu keadilan, kesejahteraan dan kebahagiaan di dunia dan juga di akhirat. Secara detail dapat dikemukakan beberapa kegunaan atau manfaat (aksiologi) dari adanya aturan hibah sepertiga bagian, yaitu sebagai berikut:

61 Tri Lisiani Prihatinah, “Tinjauan Filosofis Undang-Undang Nomor 1 Tahun 1974," Jurnal Dinamika Hukum 8, no. 2 (20 Oktober 2013): hlm. 171, https:/ / doi.org/10.20884/1.jdh.2008.8.2.61.

62 Anshori, Filsafat Hukum Sejarah, Aliran Dan Pemaknaan, hlm. 132. 
a. Adanya penetapan sepertiga bagian dalam KHI menjadikan dasar hukum agar tidak terjadi disparasi keputusan dalam masalah bagian dalam kasus hibah.

b. Adanya sebuah kepastian hukum yang dilindungi oleh negara berupa Instruksi Presiden.

c. Adanya anjuran dalam berhibah sendiri dapat membantu si penerima hibah dari berbagai kesulitan hidup, misalnya biaya pendidikan, biaya kebutuhan hidup.

d. Untuk mengakrabkan silaturahmi dan menjinakan hati serta meneguhkan kecintaan di antara sesamanya.

e. Mendapat lindungan dari Allah SWT.

f. Mengurangi kesenjangan antara kaum yang punya dengan kaum tidak punya.

g. Terhindar dari api neraka di akhir kelak. ${ }^{63}$

h. Hikmah dan manfaat dari adanya pembatasan hibah sepertiga tidak lain untuk memprioritaskan kemaslahatan bagi keluarganya diatas kepentingan orang yang bukan ahli waris. Hal ini untuk menanggulangi dari kesenjangan yang ada dalam keluarga dengan orang yang bukan dari kalangan keluarga agar tidak terjadi perpecahan.

i. Menjadikan harta berkah dan terus berkembang.

Hal ini berdasarkan pada ayat:

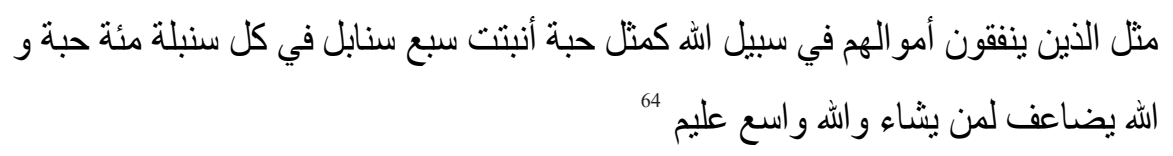

Dari ayat ini dapat dipahami tentang keberuntungan orang yang suka membelanjakan atau menyumbangkan harta bendanya

81.

63 Hamid Farihi, Hibah Terhadap Anak-Anak Dalam Keluarga (Jakarta: Pustaka Firdaus, 1995), hlm.

64 Perumpamaan (nafkah yang dikeluarkan oleh) orang-orang yang menafkahkan hartanya di jalan Allah adalah serupa dengan sebutir benih yang menumbuhkan tujuh bulir, pada tiap-tiap bulir seratus biji. Allah melipat gandakan (ganjaran) bagi siapa yang dia kehendaki. dan Allah Maha luas (karunia-Nya) lagi Maha Mengetahui. Al-Baqarah (2): 261. 
di jalan Allah. Hubungan antara infak atau pemberian dan hari akhirat adalah erat sekali karena sebagaimana diketahui, seseorang tak akan mendapat pertolongan apa pun dan dari siapa pun pada hari akhirat itu, kecuali dari hasil amalnya sendiri selagi ia masih di dunia, antara lain amalnya yang berupa infak di jalan Allah. Betapa beruntungnya orang yang suka menafkahkan hartanya di jalan Allah oleh ayat ini dilukiskan sebagai berikut : bahwa orang tersebut adalah seperti seorang yang menyemaikan sebutir benih di tanah yang subur. Benih yang sebutir itu menumbuhkan sebatang pohon dan pohon itu bercabang tujuh, setiap cabang menghasilkan setangkai buah dan setiap tangkai berisi seratus biji sehingga benih yang sebutir itu memberikan hasil sebanyak 700 butir. Ini berarti tujuh ratus kali lipat. Bayangkanlah betapa banyak hasilnya apabila benih yang ditanamnya itu lebih dari sebutir.

\section{KESIMPULAN}

Setelah penyusun mengadakan penelaahan dan pembahasan terhadap masalah-masalah yang ditarik dari pokok bahasan, akhirnya penyusun menarik kesimpulan sebagai berikut: Bahwa perumusan konsep hibah dalam hadis maupun dalam Kompilasi Hukum Islam tidak bisa dilepaskan dari batasan harta yang boleh dihibahkan, walaupun setiap orang bagian-bagiannya berbeda dalam menentukan besar kecil harta yang dihibahkan tetapi kedua aturan sepakat bahwa maksimal yaitu 1/3 bagian. Adanya batasan tersebut, tidak lain untuk memprioritaskan ahli waris atau keluarga di atas orang lain (anak angkat) dalam penerimaan harta. Karena meninggalkan ahli warisnya dalam keadaan berkecukupan lebih baik daripada meninggalkan ahli warisnya dalam keadaan miskin. Meskipun secara kepemilikan itu adalah harta si penghibah, yang dia bisa bebas melakukan apa saja dengan hartanya. Tetapi ketika ia menghibahkan seluruh hartanya kepada pihak lain dan ia tidak memiliki lagi harta untuk dibagikan kepada ahli warisnya, dan dari perbuatan ini timbul perselisihan, perpecahan dan kesenjangan antar keluarga, maka di sini mafsadahnya lebih besar daripada maslahatnya, maka lebih baik untuk dihindari. 


\section{DAFTAR PUSTAKA}

Abũ 'l-Husain Muslim ibn al Hajjãj al-Qushairī, A. 700/2:1 : Lathief Razak Rais, dan Inter Documentation Company. Shahih Muslim. Djakarta: Widjaya, 1957.

Achmadi, Asmoro. Filsafat Umum. RajaGrafindo Persada, 2001.

Agustian, Ary Ginanjar. Rahasia Sukses Membangun Kecerdasan Emosi Dan

Spiritual Esq: Emotional Spiritual Quotient Berdasarkan 6 Rukun Iman Dan 5 Rukun Islam. Jakarta: Arga Wijaya Persada, 2001.

Ahmad, Noor. Epistemologi Syara' Mencari Format Baru Fiqh Indonesia. Yogyakarta: Pustaka Pelajar, 2009.

Al-Qur'an Tajwid Warna, Terjemah Indonesia: Plus Transliterasi Latin. Shahih, 2015.

Anshori, Abdul Ghofur. Filsafat Hukum Hibah Dan Wasiat Di Indonesia. Yogyakarta: Gadjah Mada University Press, 2011.

- - - Filsafat Hukum Sejarah, Aliran Dan Pemaknaan. Yogyakarta: Gadjah Mada University Press, 2006.

Ash-Shiddieqy, Teungku Muhammad Hasbi. Figh Mawaris: Hukum Pembagian

Warisan Menurut Syariat Islam. Semarang: Pustaka Rizki Putra, 2010.

Asy-Syathibi, Abu Ishaq Ibrahim bin Musa bin Muhammad Al-Lakhmi. Al-

Muwafaqat Fi Usul Al-Shari'ah. Misr Matba'at al maktabah al-tujariyah, 1920.

Baiquni, dkk. Ensiklopedi Al-Qur'an Dunia Islam Modern. Yogyakarta: PT Dana Bhakti Prima Yasa, 2002.

Basyir, Ahmad Azhar. Asas-Asas Mu'amalah dalam Hukum Perdata Islam. Yogyakarta: Perpustakaan FH UII, 1993.

Bukhārī, Muhammad ibn Ismā‘īl. Shahih Bukhary. Al-Asriyah, Surabaya, 1979.

Djazuli, H. A. Kaidah-Kaidah Fikih: Kaidah-Kaidah Hukum Islam Dalam Menyelesaikan Masalah-Masalah Yang Praktis. Prenada Media, 2006.

Farihi, Hamid. Hibah Terhadap Anak-Anak Dalam Keluarga. Jakarta: Pustaka Firdaus, 1995.

Hasan, M. Ali. Berbagai Macam Transaksi Dalam Islam (figh Muamalat). Jakarta: RajaGrafindo Persada, 2003.

Helmi Juni, Efran. Filsafat Hukum. Cet. I. Bandung: Pustaka Setia, 1980. 
K. Lubis, Suhrawardi, dan H. Chairuman Pasaribu. Hukum Perjanjian Dalam Islam. Vol. 1994. Jakarta: Sinar Grafika, 1994.

Kansil, C. S. T. Pengantar Ilmu Hukum Dan Tata Hukum Indonesia. Jakarta: Balai Pustaka, 1989.

Manan, Abdul. Aneka Masalah Hukum Perdata Islam Di Indonesia. Jakarta: Kencana, 2006.

Mertokusumo, Sudikno. Hukum Acara Perdata Indonesia. Yogyakarta: Universitas Atma Jaya Yogyakarta, 2010.

Mudzhar, Atho, dan Mathori Alwustho. Membaca Gelombang Ijtihad: Antara Tradisi Dan Liberasi. Yogyakarta: Titian Ilahi Press, 1998.

Nursyamsudin, Nursyamsudin. "Pembagian Harta Waris Sebelum Muwaris Meninggal Dunia Menurut Perspektif Hukum Waris Islam." Mahkamah : Jurnal Kajian Hukum Islam 3, no. 1 (8 Juni 2018): 69-85. https:/ / doi. org/10.24235/mahkamah.v3i1.2747.

Oemarsalim, S. H. Dasar-Dasar Hukum Waris Di Indonesia. Bina Aksara, 1987.

Prihatinah, Tri Lisiani. “Tinjauan Filosofis Undang-Undang Nomor 1 Tahun 1974." Jurnal Dinamika Hukum 8, no. 2 (20 Oktober 2013): 166-72. https:/ / doi.org/10.20884/1.jdh.2008.8.2.61.

Prodjodikoro, Wirjono. Hukum Warisan Di Indonesia. Bandung: Sumur Bandung, 1983.

Rajasa, Sutan. Kamus Ilmiah Populer. Surabaya: Karya Utama, 2002.

Rofiq, Ahmad. Hukum Islam Di Indonesia. RajaGrafindo Persada, 1995.

Sabiq, al-Sayyid. Fiqih Sunnah. Jakarta, Indonesia: Pena Pundi Aksara, 2008. Sanjaya, Umar Haris. "Kedudukan Surat Wasiat Terhadap Harta Warisan Yang Belum Dibagikan Kepada Ahli Waris." Jurnal Yuridis 5, no. 1 (2 Agustus 2018): 67-97. https:// doi.org/10.35586/.v5i1.317.

Setiawan, R. Pokok-Pokok Hukum Perikatan. Cet. 5. Bandung: Bina Cipta, 1994.

Shiddieqy, Muhammad Hasbi Ash-. Peradilan Dan Hukum Acara Islam. PT. Alma'arif, Jakarta, 1984.

Shobirin. "Ahli Waris Pengganti dalam Kewarisan Islam Perspektif Mazhab Nasional." Ahli Waris Pengganti dalam Kewarisan Islam Perspektif Mazhab- 
Nasional (blog). Diakses 30 Januari 2013. http://www.badilag.net/liputan-rakernas-2011/434-artikel.

Sjafa' at. Pengantar Studi Islam. Cet. I. Jakarta: Bulan Bintang, 1964.

Sudarsono, S. H. Kamus Hukum, 1992.

Tamam, Ahmad Badrut. "Hibah : Sebuah Tawaran Solusi bagi Problematika Hukum Waris Islam." Diktat dipresentasikan pada Program Pascasarjana UIN Suka, Yogyakarta, 2010.

Wahyudi, Rahmat. "Hibah Melebihi Sepertiga Harta (Studi Kasus di desa Bonagung Kecamatan Tanon Kabupaten Sragen." IAIN Walisongo, 2011. 